\title{
Reduction of Trace Quantities of Chromium(VI) by Strong Acids
}

\author{
Sérgio H. Pezzin ${ }^{*, a}$, José F. Lugo Rivera ${ }^{b}$, Carol H. Collins ${ }^{c}$ and Kenneth E. Collins ${ }^{*, c}$ \\ ${ }^{a}$ Centro de Ciências Tecnológicas - UDESC, 89223-100 Joinville - SC, Brazil \\ ${ }^{b}$ Centro Regional de Estudios Nucleares, Universidad Autónoma de Zacatecas, 98000 Zacatecas, ZAC, Mexico \\ ${ }^{c}$ Instituto de Química, Universidade Estadual de Campinas, CP6154, 13084-971 Campinas - SP, Brazil
}

\begin{abstract}
O comportamento químico de $\mathrm{Cr}(\mathrm{VI})$ a baixas concentrações $\left(10^{-4}\right.$ to $\left.10^{-7} \mathrm{~mol} \mathrm{~L} \mathrm{~L}^{-1}\right)$ em vários ácidos fortes foi estudado utilizando-se ${ }^{51} \mathrm{Cr}(\mathrm{VI})$ de alta atividade específica como marcador. A especiação dos produtos destes sistemas foi realizada por cromatografia de troca iônica com eluição em etapas. Os resultados mostram que traços de $\mathrm{Cr}(\mathrm{VI})$, monitorados por radiocromo $\left({ }^{51} \mathrm{Cr}\right)$, são reduzidos na presença de ácidos minerais tais como perclórico, clorídrico, fluorídrico, sulfúrico, nítrico e trifluormetanosulfônico, mesmo na ausência de agentes redutores convencionais, produzindo várias espécies de $\mathrm{Cr}(\mathrm{IIII})$ diferentes, dependendo do ânion do ácido. Estudos detalhados com soluções de ácido nítrico mostram que a velocidade relativa da redução aumenta com o aumento da concentração do ácido ou com o decréscimo da concentração de $\mathrm{Cr}(\mathrm{VI})$.
\end{abstract}

The chemical behavior of $\mathrm{Cr}(\mathrm{VI})$ at low concentrations $\left(10^{-4}\right.$ to $\left.10^{-7} \mathrm{~mol} \mathrm{~L}^{-1}\right)$ in several strong acids was studied using high specific activity ${ }^{51} \mathrm{Cr}(\mathrm{VI})$ as a tracer. The speciation of the products from these systems was carried out by ion exchange chromatography with stepwise elution. The results show that trace quantities of $\mathrm{Cr}(\mathrm{VI})$, monitored by means of radiochromium $\left({ }^{51} \mathrm{Cr}\right)$, are reduced in the presence of mineral acids such as perchloric, hydrochloric, hydrofluoric, sulfuric, nitric and trifluoromethanesulfonic acids, even in the absence of conventional reducing agents, producing different measureable $\mathrm{Cr}$ (III) species, depending on the acid anion. Detailed studies of the reduction of low concentrations of $\mathrm{Cr}(\mathrm{VI})$ with nitric acid have shown that the relative rate of reduction increases as the concentration of the acid increases or as the concentration of the $\mathrm{Cr}(\mathrm{VI})$ decreases.

Keywords: chromium, chromate, speciation, ion exchange chromatography, acid reduction

\section{Introduction}

The acid reduction of $\mathrm{Cr}(\mathrm{VI})$ is a little known aspect of chromium chemistry even though the reduction of $\mathrm{Cr}(\mathrm{VI})$ by hydrochloric acid has been known since the discovery of the element by Vauquelin in 1797. He described the formation of a green solution of $\mathrm{Cr}$ (III) when dissolving the mineral chrocoite, $\mathrm{PbCrO}_{4}$, in muriatic acid. ${ }^{1}$ In the 40 's, Feigl ${ }^{2}$ suggested the reaction of hydrochloric acid and potassium chromate, with manganese dioxide as catalyst, as a spot reaction experiment for educational purposes.

The oxidation of organic compounds by $\mathrm{Cr}(\mathrm{VI})$ in acidic media has been studied and reviewed by many authors. ${ }^{3-6} \mathrm{~A}$ great variety of $\mathrm{Cr}(\mathrm{VI})$ compounds have proved to be versatile reagents capable of oxidizing almost every

*e-mail:dcb2shp@joinville.udesc.br; kec@iqm.unicamp.br oxidizable organic functional group. Beattie and Haight ${ }^{7}$ reviewed $\mathrm{Cr}(\mathrm{VI})$ oxidations of inorganic substrates, while Fendorf et al. ${ }^{8}$ concerned themselves with the role of biological and abiological processes in chromium(VI) reductions.

The reduction of $\mathrm{Cr}(\mathrm{VI})$ by many acids, including the so-called "oxidizing acids", has also been reported. ${ }^{9-19}$ Detailed studies of the reduction of low concentrations (less than $10^{-3} \mathrm{~mol} \mathrm{~L}^{-1}$ ) of $\mathrm{Cr}(\mathrm{VI})$ with several different acids, including $\mathrm{HNO}_{3},{ }^{13,14} \mathrm{HClO}_{4},{ }^{17} \mathrm{CF}_{3} \mathrm{SO}_{3} \mathrm{H}^{1,}{ }^{17} \mathrm{H}_{2} \mathrm{SO}_{4},{ }^{18}$ and $\mathrm{HCl},{ }^{18}$ have shown that the relative rate of reduction increases as the concentration of the acid increases or as the concentration of the $\mathrm{Cr}(\mathrm{VI})$ decreases. Similar reductions have been reported for $\mathrm{Cr}(\mathrm{VI})$ present in natural waters, after acidification of the sample for storage..$^{20,21}$ These results are apparently not consistent with the wellknown use of acidic $\mathrm{Cr}(\mathrm{VI})$ solutions as titrimetric and spectrophotometric standards..$^{22}$ 
A number of mechanisms have been proposed for reduction of $\mathrm{Cr}(\mathrm{VI})$ involving combinations of one-, two and three-electron elementary processes. The variety of species of chromium(VI) in acid solution, the passage of chromium through transient, unstable species of $\mathrm{Cr}(\mathrm{V})$ and $\mathrm{Cr}(\mathrm{IV})$, and the formation of complexes of chromium(III) all combine to give systems of considerable complexity. Thus, King and coworkers ${ }^{23,24}$ suggested a sequence of three one-electron steps for the reduction of $\mathrm{Cr}(\mathrm{VI})$ to $\mathrm{Cr}(\mathrm{III})$, with the step from $\mathrm{Cr}(\mathrm{V})$ to $\mathrm{Cr}(\mathrm{IV})$ being the slowest, due to the change in coordination number from four to six, while Khan and $\operatorname{Din}^{25}$ propose a single, three-electron reduction after the formation of a diester. Esters have also been implicated in the oxidation of organic substrates by $\mathrm{Cr}(\mathrm{VI}){ }^{3}$

Haight et al. ${ }^{26}$ attributed the reduction in perchloric acid to the action of water. However, this is not likely to be the case as the rate of reduction increases with a decrease in the activity of water, as seen in the extreme cases of $98 \%$ $\mathrm{H}_{2} \mathrm{SO}_{4}{ }^{18}$ and $99 \% \mathrm{CF}_{3} \mathrm{SO}_{3} \mathrm{H}^{.17}$ Stollenwerk and Grove ${ }^{21}$ suggest that the electrons for the $\mathrm{Cr}(\mathrm{VI})$ reduction could be provided by the oxygen in $\mathrm{HCrO}_{4}^{-}$while Espenson ${ }^{27}$ suggests the addition of protons, two for the first step (Cr(VI) to $\mathrm{Cr}(\mathrm{V}))$ and one for the second $(\mathrm{Cr}(\mathrm{V})$ to $\mathrm{Cr}(\mathrm{IV}))$. However, no satisfactory overall reaction mechanism for the acid reduction of $\mathrm{Cr}(\mathrm{VI})$ has yet been proposed.

Studies of the reaction of solid $\mathrm{CrO}_{3}$ with concentrated $\mathrm{HClO}_{4},{ }^{15} \mathrm{HNO}_{3}{ }^{19}$ or $\mathrm{HCl}^{28}$ show that the acid-reduction process depends on the solubilization of the $\mathrm{Cr}(\mathrm{VI})$. Low concentrations of $\mathrm{Cr}(\mathrm{VI})$ in the solution phase lead to a very rapid reduction, but $\mathrm{Cr}(\mathrm{VI})$ concentrations above $10^{-2} \mathrm{~mol} \mathrm{~L}^{-1}$ are also reduced, although the process is slower. The rate of reduction in the $\mathrm{CrO}_{3}-37 \% \mathrm{HCl}$ system is very rapid, when compared to the rates for the $\mathrm{CrO}_{3}-70 \% \mathrm{HClO}_{4}$ and $\mathrm{CrO}_{3}-65 \% \mathrm{HNO}_{3}$ systems, probably due to the presence of the oxidizable chloride ion. Based on ion exchange analysis and aquation experiments, it was concluded ${ }^{28}$ that the initial identifiable species produced by the reduction reaction is $\left[\mathrm{Cr}\left(\mathrm{H}_{2} \mathrm{O}\right)_{3} \mathrm{Cl}_{3}\right]$, which undergoes aquation to produce $\left[\mathrm{Cr}\left(\mathrm{H}_{2} \mathrm{O}\right)_{4} \mathrm{Cl}_{2}\right]^{+},\left[\mathrm{Cr}\left(\mathrm{H}_{2} \mathrm{O}\right)_{5} \mathrm{Cl}\right]^{2+}$ and, finally, $\left[\mathrm{Cr}\left(\mathrm{H}_{2} \mathrm{O}\right)_{6}\right]^{3+}$.

These results show the importance of $\mathrm{Cr}(\mathrm{VI})$ concentrations to the acid reduction process. Which species of $\mathrm{Cr}(\mathrm{VI})$ are present in acidic solution, their spectra and their equilibria are the subjects of considerable discussion in the literature. ${ }^{29,30}$ Besides the divergences regarding the existence of the protonated species, $\mathrm{HCrO}_{4}^{-}$and $\mathrm{H}_{2} \mathrm{CrO}_{4}$, there are also differences of opinion about the range of predominance of each species as a function of $\mathrm{pH}, \mathrm{Cr}(\mathrm{VI})$ concentration and ionic strength. ${ }^{30-32}$ From all these discussions, it is possible to propose some general guidelines for the existence and distribution of the different $\mathrm{Cr}(\mathrm{VI})$ species. In the $\mathrm{pH}$ range from 1 to 6 , the $\mathrm{HCrO}_{4}^{-}$ion predominates when the $[\mathrm{Cr}(\mathrm{VI})]$ is $<10^{-3} \mathrm{~mol} \mathrm{~L}^{-1} . \mathrm{Cr}_{2} \mathrm{O}_{7}{ }^{2-}$ becomes important only at higher $\mathrm{Cr}(\mathrm{VI})$ concentrations. The species dihydrogen chromate, $\mathrm{H}_{2} \mathrm{CrO}_{4}$, may also exist at $\mathrm{pH}<1$. Moreover, the $\mathrm{Cr}(\mathrm{VI})$ equilibria depend on the nature of the acid used. Changes in the electronic absorption spectra of $\mathrm{HCrO}_{4}^{-}$in the presence of various acids, such as $\mathrm{H}_{2} \mathrm{SO}_{4}, \mathrm{H}_{3} \mathrm{PO}_{4}, \mathrm{HCl}$, and $\mathrm{H}_{2} \mathrm{C}_{2} \mathrm{O}_{4}$, are interpreted ${ }^{7}$ as indicating formation of the esters $\mathrm{CrSO}_{7}^{2-}$, $\mathrm{HCrPO}_{7}^{2-}, \mathrm{CrO}_{3} \mathrm{Cl}^{-}$, and $\mathrm{H}_{2} \mathrm{CrO}_{3} \mathrm{C}_{2} \mathrm{O}_{4}$.

On the other hand, the wide utilization of chromium and its compounds by modern industry results in the discharge of large quantities of this element into the environment. In view of its paradoxical roles as an essential micronutrient in human and animal nutrition at low concentrations, as $\mathrm{Cr}(\mathrm{III})$, and as a known carcinogen at elevated levels, as $\mathrm{Cr}(\mathrm{VI})$, there is a growing concern about the fate and effects of chromium in the environment. ${ }^{33}$ Thus, chromium speciation is an important analytical operation for laboratories that determine chromium in natural water, in drinking water or in other consumables. Although chromium can be present in aqueous solutions as $\mathrm{Cr}(\mathrm{VI})$ or as any of various kinetically stable forms of $\mathrm{Cr}$ (III), whose distribution depends on the chemical history of the aqueous sample, most chromium speciation procedures in the literature consider only $\mathrm{Cr}(\mathrm{VI})$ and $\mathrm{Cr}(\mathrm{III})$ (as the hexaaquo species) as significant. Thus, a number of liquid chromatographic methods have recently been proposed to separate $\mathrm{Cr}(\mathrm{VI})$ and the several $\mathrm{Cr}(\mathrm{III})$ species. ${ }^{34,35}$

This paper discusses the reduction of $\mathrm{Cr}(\mathrm{VI})$ in several concentrated mineral acids, in the absence of any other reducing agent, and the determination of its products by ion exchange procedures. These procedures have been used in the fraction collection mode, with radiometric detection of Cr-51-labelled species.

\section{Experimental}

\section{Reagents}

Triply-distilled and deionized water (Nanopure, Barnstead or Milli-Q, Millipore) was used in all procedures. For the acid reduction experiments, analytical grade $70 \%$ perchloric (Aldrich, 99,999\% pure), 40\% hydrofluoric (Nuclear), 37\% hydrochloric (Merck), 65\% nitric (CPQ), 98\% sulfuric (Merck), and $99 \%$ trifluoromethanesulfonic acids (Aldrich) were used.

${ }^{51} \mathrm{Cr}(\mathrm{VI})$ was obtained as an aqueous solution of $\mathrm{Na}_{2}^{51} \mathrm{CrO}_{4}$ (Amersham, England). The specific activity was $400 \mathrm{GBq} \mathrm{mol}^{-1}$. All samples were submitted to multichanel 
(EG\&G Ortec 918) radionuclidic analysis which utilized the $0.320 \mathrm{MeV}$ peak of ${ }^{51} \mathrm{Cr}$. Open column cation-exchange radiochromatography ${ }^{36}$ was carried out to show that more than $99 \%$ of the ${ }^{51} \mathrm{Cr}$ was initially present as $\mathrm{Cr}(\mathrm{VI})$.

\section{Reaction of trace Cr(VI) with concentrated acids}

To $5 \mathrm{~mL}$ screw-capped Erlenmeyer flasks were added $1.0 \mathrm{~mL}$ of acid $\left(70 \% \mathrm{HClO}_{4}\right.$ or $40 \% \mathrm{HF}$ or $37 \% \mathrm{HCl}$ or $65 \%$ $\mathrm{HNO}_{3}$ or $98 \% \mathrm{H}_{2} \mathrm{SO}_{4}$ or $\left.99 \% \mathrm{CF}_{3} \mathrm{SO}_{3} \mathrm{H}\right)$ and $100 \mu \mathrm{L}$ of high specific activity ${ }^{51} \mathrm{Cr}(\mathrm{VI})$. The initial concentrations of $\mathrm{Cr}(\mathrm{VI})$ varied from $1 \times 10^{-5}$ to $2.3 \times 10^{-5} \mathrm{~mol} \mathrm{~L}^{-1}$. The solutions were homogenized and maintained at room temperature $\left(19.6-20.6^{\circ} \mathrm{C}\right)$. After appropriate time periods, $10 \mu \mathrm{L}$ aliquots were taken and immediately analyzed or diluted in water ("aquation solutions") for later analysis by ion exchange chromatography.

\section{Reaction of trace Cr(VI) with nitric acid solutions}

A set of acidic solutions of $\mathrm{Cr}(\mathrm{VI})$ with concentrations from $10^{-7}$ to $10^{-3} \mathrm{~mol} \mathrm{~L}^{-1}$ were prepared in nitric acid whose concentration varied from 2 to $10^{-5} \mathrm{~mol} \mathrm{~L}^{-1}$. The $10^{-7}$ to $10^{-5} \mathrm{~mol} \mathrm{~L}^{-1} \mathrm{Cr}(\mathrm{VI})$ solutions were prepared directly from the radioactive solution, whereas those of $10^{-4}$ and $10^{-3}$ mol L $\mathrm{L}^{-1} \mathrm{Cr}(\mathrm{VI})$ were prepared from a stock solution of $\mathrm{K}_{2} \mathrm{Cr}_{2} \mathrm{O}_{7}$ and spiked with ${ }^{51} \mathrm{Cr}(\mathrm{VI})$. All the solutions were stored in glass flasks in the absence of light. After appropriate time periods, aliquots of these solutions were analyzed by ion exchange chromatography.

\section{Speciation by open column ion exchange chromatography}

Ion exchange columns were prepared by placing 0.5 $\mathrm{mL}$ of pretreated ${ }^{37}$ cation (Bio-Rad AG50Wx8, 100-200, $\mathrm{Na}^{+}$form) or anion (BioRad AG1x8, 200-400 mesh, $\mathrm{Cl}^{-}$ form) resins in glass columns (40-80 $\mathrm{mm} \times 5 \mathrm{~mm}$ ) fitted with a PTFE stopcock and having a small $(7-8 \mathrm{~mL})$ open reservoir at the top. ${ }^{38}$ Just prior to use, the cation resin was treated with $0.5 \mathrm{~mL}$ of a $0.02 \mathrm{~mol} \mathrm{~L}^{-1} \mathrm{Na}_{2} \mathrm{Cr}_{2} \mathrm{O}_{7}$ solution (to eliminate possible reducing impurities) and washed with $6 \mathrm{~mL}$ of $0.01 \mathrm{~mol} \mathrm{~L}^{-1} \mathrm{HClO}_{4}$ and $10 \mathrm{~mL}$ of deionized water. Then, $0.01 \mathrm{~mL}$ of sample solution containing a few micromoles of the ionic species, as carrier, was added to 4 $\mathrm{mL}$ of deionized water contained in the open reservoir. This procedure is required to decrease the high initial acid concentration. After the liquid level reached the top of the resin bed, a small portion of the first eluent was used to carefully rinse the walls. The elution was carried out using the following sequence of eluents: $12 \mathrm{~mL}$ of $0.01 \mathrm{~mol} \mathrm{~L}^{-1}$ $\mathrm{HClO}_{4}$ for the elution of neutral and anionic species; 20
$\mathrm{mL}$ of $0.1 \mathrm{~mol} \mathrm{~L}^{-1} \mathrm{HClO}_{4}$ for the elution of +1 species; 20 $\mathrm{mL}$ of $1 \mathrm{~mol} \mathrm{~L}^{-1} \mathrm{HClO}_{4}$ for the elution of +2 species; $24 \mathrm{~mL}$ of $0.25 \mathrm{~mol} \mathrm{~L}^{-1} \mathrm{Ca}\left(\mathrm{ClO}_{4}\right)_{2}$ at $\mathrm{pH} 2$ (adjusted with $\mathrm{HClO}_{4}$ ) for the elution of +3 species; $24 \mathrm{~mL}$ of $0.5 \mathrm{~mol} \mathrm{~L}^{-1} \mathrm{Ca}\left(\mathrm{ClO}_{4}\right)_{2}$ at $\mathrm{pH} 2$ and $24 \mathrm{~mL}$ of $1 \mathrm{~mol} \mathrm{~L}^{-1} \mathrm{Ca}\left(\mathrm{ClO}_{4}\right)_{2}$ at $\mathrm{pH} 2$ for the elution of dimeric, trimeric and polimeric species. ${ }^{36}$

Two $\mathrm{mL}$ fractions of the eluates were collected (ISCO 328 fraction collector) for radioactivity measurements. The resin $(\mathrm{R})$ was also counted to estimate possible non-eluting species. In some experiments, to distinguish between the anionic (A) and neutral $(\mathrm{N})$ species which co-elute in the first fraction, a $0.01 \mathrm{~mL}$ aliquot of this fraction was analyzed by anion exchange chromatography on Bio-Rad AG-1 resin, using $8 \mathrm{~mL}$ of $0.01 \mathrm{~mol} \mathrm{~L}^{-1} \mathrm{HClO}_{4}$ as eluent. The $0.320 \mathrm{MeV}$ gamma rays from the decay of ${ }^{51} \mathrm{Cr}$ were measured using a well type $\mathrm{NaI}(\mathrm{Tl})$ detector (Bicron) coupled to a modular single channel gamma analyzer (Hewlett-Packard 5583A). The counting time was determined by the sample activities to give errors below $1 \%$, as counting statistics give an estimate of the measurement standard deviation as $\pm \sqrt{ } \mathrm{N}$, where $\mathrm{N}$ is the number of counts recorded.

\section{Results and Discussion}

\section{The reaction of trace $C r(V I)$ with hydrochloric acid}

The cation exchange chromatogram of the products formed when a high specific activity ${ }^{51} \mathrm{Cr}(\mathrm{VI})$ solution was placed in concentrated hydrochloric acid, and stored for $60 \mathrm{~min}$, is shown in Figure 1. In this case, $85 \%$ of the ${ }^{51} \mathrm{Cr}$ eluted with the initial solution, indicating the presence of anionic or neutral species, smaller amounts of ${ }^{51} \mathrm{Cr}$ appearing in subsequent fractions. The anion exchange analysis confirmed the presence of only neutral species, with no residual ${ }^{51} \mathrm{Cr}(\mathrm{VI})$, suggesting that the species eluted in the initial cation fraction is $\mathrm{Cr}\left(\mathrm{H}_{2} \mathrm{O}\right)_{3} \mathrm{Cl}_{3}$. In addition, when the reaction product mixture was stored in $0.05 \mathrm{~mol}$ $\mathrm{L}^{-1} \mathrm{HCl}$, the composition of the mixture slowly changed, indicating aquation of the $\mathrm{Cr}(\mathrm{III})$-chloride complexes. Initially, $\mathrm{Cr}\left(\mathrm{H}_{2} \mathrm{O}\right)_{4} \mathrm{Cl}_{2}^{+}$and $\mathrm{Cr}\left(\mathrm{H}_{2} \mathrm{O}\right)_{5} \mathrm{Cl}^{2+}$ were produced but, after $168 \mathrm{~h}$, nearly $30 \%$ of the product was hexaaquochromium(III), $\mathrm{Cr}\left(\mathrm{H}_{2} \mathrm{O}\right)_{6}{ }^{3+}$ (Figure 1 and Table 1). The identities of the species as $\mathrm{Cr}\left(\mathrm{H}_{2} \mathrm{O}\right)_{4} \mathrm{Cl}_{2}{ }^{+}$and $\mathrm{Cr}\left(\mathrm{H}_{2} \mathrm{O}\right)_{5} \mathrm{Cl}^{2+}$ are based on cation exchange determinations, with spectrophotometric confirmation, using aqueous solutions of $\mathrm{CrCl}_{3} \cdot{ }^{39}$

As has been known for many decades, $\mathrm{Cr}(\mathrm{VI})$ reduction in concentrated $\mathrm{HCl}$ involves the oxidation of chloride to chlorine.$^{40}$ Krauss et al. ${ }^{41}$ studied the $\mathrm{HCl} / \mathrm{CrO}_{3}$ reaction in acetic acid spectrophotometrically and proposed a one- 


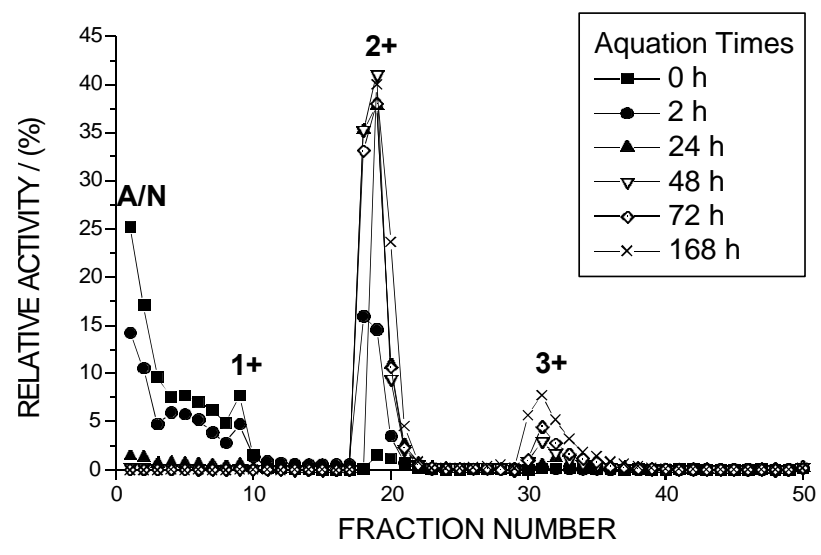

Figure 1. Cation exchange chromatograms of the products from the reaction $(1 \mathrm{~h})$ of high specific activity ${ }^{51} \mathrm{Cr}(\mathrm{VI})$ and $37 \% \mathrm{HCl}$ and after post reduction aquation.

Table 1. Summary of products (\%), observed after different reaction times, $\mathrm{t}$ (conc), and after specified aquation times, $\mathrm{t}(\mathrm{dil})$, from trace ${ }^{51} \mathrm{Cr}(\mathrm{VI})$ reacting with concentrated $\mathrm{HCl}$

\begin{tabular}{lcccccc}
\hline $\mathrm{t}$ (conc) & $\mathrm{t}$ (dil) & $\begin{array}{c}\text { Anionic/ } \\
\text { Neutral }\end{array}$ & $\begin{array}{c}\text { Charge } \\
1+\end{array}$ & $\begin{array}{c}\text { Charge } \\
2+\end{array}$ & $\begin{array}{c}\text { Charge } \\
3+\end{array}$ & Resin \\
\hline $1 \mathrm{~h}$ & 0 & 85.4 & 9.7 & 3.8 & 0.8 & 0.3 \\
$1 \mathrm{~h}$ & $2 \mathrm{~h}$ & 53.2 & 10.6 & 35.2 & 0.8 & 0.3 \\
$1 \mathrm{~h}$ & $24 \mathrm{~h}$ & 6.1 & 1.5 & 88.0 & 3.9 & 0.5 \\
$1 \mathrm{~h}$ & $48 \mathrm{~h}$ & 1.0 & 0.4 & 89.7 & 8.3 & 0.7 \\
$1 \mathrm{~h}$ & $72 \mathrm{~h}$ & 0.4 & 0.3 & 85.6 & 13.0 & 0.7 \\
$1 \mathrm{~h}$ & $168 \mathrm{~h}$ & 0.2 & 0.3 & 71.0 & 27.6 & 0.9 \\
$840 \mathrm{~h}$ & 0 & 80.9 & 11.8 & 7.3 & - & - \\
\hline
\end{tabular}

electron reduction mechanism, with the formation of $\left[\mathrm{Cr}^{\mathrm{V}} \mathrm{OCl}_{5}\right]^{2-}$ and further reduction to $\mathrm{H}_{2}\left[\mathrm{Cr}\left(\mathrm{H}_{2} \mathrm{O}\right) \mathrm{Cl}_{5}\right]$. Thus, in the $\mathrm{Cr}(\mathrm{VI})-\mathrm{HCl}$ system, the oxidation of chloride to chlorine by $\mathrm{Cr}(\mathrm{VI})$ may be an important reaction but other paths may also contribute.

\section{The reaction of trace $\mathrm{Cr}(\mathrm{VI})$ with hydrofluoric acid}

The results for the immediate ( $5 \mathrm{~min}$ ) cation exchange analysis showed that $91 \%$ of the ${ }^{51} \mathrm{Cr}$ was eluted as anionic and/or neutral species, $5 \%$ as $1+$ species, $2 \%$ as $2+$ species and $<2 \%$ as $3+$ species (Figure 2 and Table 2). The chromatographic profile was very similar to that obtained for the $\mathrm{Cr}(\mathrm{VI})-\mathrm{HCl}$ system, so the species identifications were made by analogy. Aquation, however, was much slower. An analysis carried out after $192 \mathrm{~h}$ of storage at $\mathrm{pH}$ 2 showed that $81 \%$ of the ${ }^{51} \mathrm{Cr}$ still eluted as neutral species.

\section{The reaction of trace $\mathrm{Cr}(\mathrm{VI})$ with sulfuric acid}

The results from coupled cation exchange-anion exchange determination of the products from the reaction

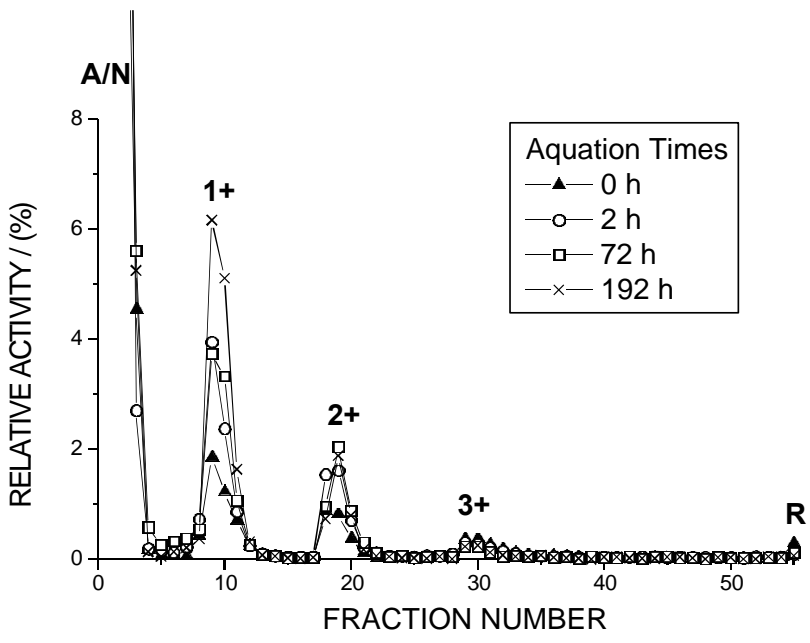

Figure 2. Cation exchange chromatograms of the products from the reaction $(1 \mathrm{~h})$ of high specific activity ${ }^{51} \mathrm{Cr}(\mathrm{VI})$ and $40 \% \mathrm{HF}$ and after post reduction aquation.

Table 2. Summary of products (\%), observed after different reaction times, $\mathrm{t}$ (conc), and after specified aquation times, $\mathrm{t}(\mathrm{dil})$, from trace ${ }^{51} \mathrm{Cr}(\mathrm{VI})$ reacting with concentrated $\mathrm{HF}$

\begin{tabular}{lcccccc}
\hline $\mathrm{t}$ (conc) & $\mathrm{t}$ (dil) & $\begin{array}{c}\text { Anionic/ } \\
\text { Neutral }\end{array}$ & $\begin{array}{c}\text { Charge } \\
1+\end{array}$ & $\begin{array}{c}\text { Charge } \\
2+\end{array}$ & $\begin{array}{c}\text { Charge } \\
3+\end{array}$ & Resin \\
\hline $1 \mathrm{~h}$ & 0 & 90.8 & 4.6 & 2.3 & 1.5 & 0.7 \\
$1 \mathrm{~h}$ & $2 \mathrm{~h}$ & 85.1 & 8.4 & 4.5 & 1.3 & 0.6 \\
$1 \mathrm{~h}$ & $72 \mathrm{~h}$ & 85.5 & 8.6 & 4.5 & 0.9 & 0.5 \\
$1 \mathrm{~h}$ & $192 \mathrm{~h}$ & 80.9 & 13.8 & 2.8 & 0.9 & 0.5 \\
\hline
\end{tabular}

(1 h) of high specific activity ${ }^{51} \mathrm{Cr}(\mathrm{VI})$ with $\mathrm{H}_{2} \mathrm{SO}_{4}$ showed that almost $100 \%$ was an anionic species. When stored in $0.09 \mathrm{~mol} \mathrm{~L}^{-1} \mathrm{H}_{2} \mathrm{SO}_{4}$, a slow aquation was noted, producing $\mathrm{Cr}\left(\mathrm{H}_{2} \mathrm{O}\right)_{2} \mathrm{SO}_{4}{ }^{+}$and $\mathrm{Cr}\left(\mathrm{H}_{2} \mathrm{O}\right)_{6}{ }^{3+}$ (Figure 3 and Table 3). The aquation of the complexes formed from the reaction with $\mathrm{H}_{2} \mathrm{SO}_{4}$ was slower than with $\mathrm{HCl}$, producing about $20 \%$ each of $1+$ and $3+$ species after $168 \mathrm{~h}$. After 3 months of storage in diluted acid, only $4 \%$ of the ${ }^{51} \mathrm{Cr}$ remained as anionic or neutral species, indicating that the initial species, produced in one hour of reaction in the ${ }^{51} \mathrm{Cr}(\mathrm{VI})$ $\mathrm{H}_{2} \mathrm{SO}_{4}$ system, was $\mathrm{Cr}\left(\mathrm{H}_{2} \mathrm{O}\right)_{2}\left(\mathrm{SO}_{4}\right)_{2} \cdot{ }^{-42}$

\section{The reaction of trace Cr(VI) with perchloric acid}

When a high specific activity ${ }^{51} \mathrm{Cr}(\mathrm{VI})$ solution and concentrated perchloric acid were stirred for $25 \mathrm{~min}$ and an aliquot was added directly to water in the column reservoir, $82 \%$ of the ${ }^{51} \mathrm{Cr}$ was observed as hexaaquochromium(III), $14 \%$ as a $2+$ species and $3 \%$ as a $1+$ species. Moreover, only $0.6 \%$ of the total ${ }^{51} \mathrm{Cr}$ was as an anionic species. The identities of the lesser charged species as $\mathrm{Cr}\left(\mathrm{ClO}_{4}\right)^{2+}$ and $\mathrm{Cr}\left(\mathrm{ClO}_{4}\right)_{2}^{+}$were made by analogy to 


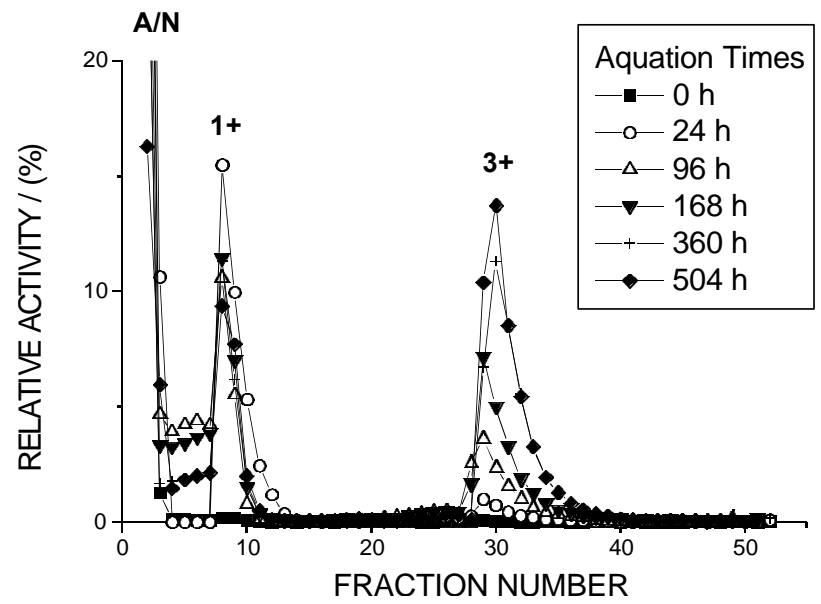

Figure 3. Cation exchange chromatograms of the products from the reaction (1h) of high specific activity ${ }^{51} \mathrm{Cr}(\mathrm{VI})$ and $98 \% \mathrm{H}_{2} \mathrm{SO}_{4}$ after post reduction aquation.

Table 3. Summary of products (\%), observed after different reaction times, $\mathrm{t}(\mathrm{conc})$, and after specified aquation times, $\mathrm{t}(\mathrm{dil})$, from trace ${ }^{51} \mathrm{Cr}(\mathrm{VI})$ reacting with concentrated $\mathrm{H}_{2} \mathrm{SO}_{4}$

\begin{tabular}{lcccccc}
\hline $\mathrm{t}$ (conc) & $\mathrm{t} \mathrm{(dil)}$ & $\begin{array}{c}\text { Anionic/ } \\
\text { Neutral }\end{array}$ & $\begin{array}{c}\text { Charge } \\
1+\end{array}$ & $\begin{array}{c}\text { Charge } \\
2+\end{array}$ & $\begin{array}{c}\text { Charge } \\
3+\end{array}$ & Resin \\
\hline $1 \mathrm{~h}$ & 0 & 99.5 & 0.5 & - & - & -- \\
$1 \mathrm{~h}$ & $24 \mathrm{~h}$ & 60.0 & 37.0 & - & 3.0 & - \\
$1 \mathrm{~h}$ & $96 \mathrm{~h}$ & 67 & 20 & - & 13 & - \\
$1 \mathrm{~h}$ & $168 \mathrm{~h}$ & 54 & 23 & - & 23 & - \\
$1 \mathrm{~h}$ & $360 \mathrm{~h}$ & 39 & 20 & - & 41 & - \\
$1 \mathrm{~h}$ & $504 \mathrm{~h}$ & 29 & 22 & - & 49 & - \\
$1 \mathrm{~h}$ & $2200 \mathrm{~h}$ & 4 & 20 & - & 76 & \\
$24 \mathrm{~h}$ & 0 & 100 & - & - & - & - \\
\hline
\end{tabular}

species of similar charge found by cation exchange determinations of aqueous solutions of $\mathrm{CrCl}_{3}{ }^{36}$ and $\mathrm{Cr}(\mathrm{SCN})_{3}{ }^{43}$ since no other anion is present. Charged perchlorate complexes with $\mathrm{Cr}(\mathrm{III})$ in concentrated perchloric acid have been reported, ${ }^{44,45}$ based on spectrophotometric determinations. The results show that, in the reduction of $\mathrm{Cr}(\mathrm{VI})$ in concentrated perchloric acid, the formation of chromium-perchlorate complexes takes place and, despite moderately rapid aquation, these complexes can be characterized by chromatographic methods.

When the chromatographic analysis of high specific activity ${ }^{51} \mathrm{Cr}(\mathrm{VI})$ in concentrated $\mathrm{HClO}_{4}$ is carried out immediately after mixing ( $c a .5 \mathrm{~min}$ ), the principal species was also the $3+$ species $(68 \%)$, with a significant amount of $2+$ complex $(24 \%)$ and some of $1+$ complexes $(3 \%)$. Here, anionic and neutral species were responsible for $\sim 4 \%$ of the ${ }^{51} \mathrm{Cr}$, while $2 \%$ remained on the resin. To further investigate the stability of these species, aliquots from the systems were diluted with water and analyzed after defined storage times (Figure 4). Analysis after 96 hours at $\mathrm{pH} 2$ showed that the $3+$ species had increased to $73 \%$, while the $2+$ species decreased to $16 \%$. Table 4 summarizes the results obtained in these studies. The possible neutral species $\left(\mathrm{CrO}_{2}\left(\mathrm{ClO}_{4}\right)_{2}\right)^{46}$ was either not formed or underwent hydrolysis before analysis could be started, forming the observed cationic species.

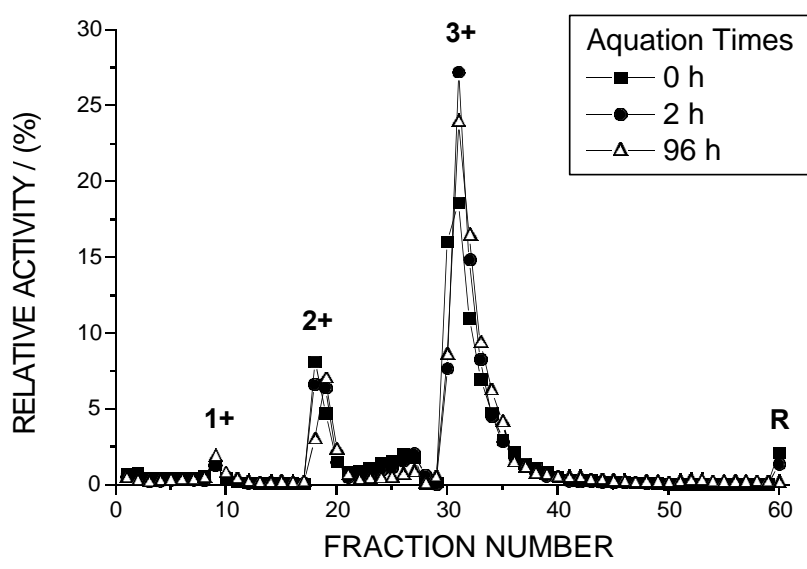

Figure 4. Cation exchange chromatograms of the products from the reaction $(5 \mathrm{~min})$ of high specific activity ${ }^{51} \mathrm{Cr}(\mathrm{VI})$ and $70 \% \mathrm{HClO}_{4}$ and after post reduction aquation.

Table 4. Summary of products (\%), observed after different reaction times, $t($ conc $)$, and after specified aquation times, $t(d i l)$, from trace ${ }^{51} \mathrm{Cr}(\mathrm{VI})$ reacting with concentrated $\mathrm{HClO}_{4}$

\begin{tabular}{lcccccc}
\hline $\mathrm{t}$ (conc) & $\mathrm{t}$ (dil) & $\begin{array}{c}\text { Anionic/ } \\
\text { Neutral }\end{array}$ & $\begin{array}{c}\text { Charge } \\
1+\end{array}$ & $\begin{array}{c}\text { Charge } \\
2+\end{array}$ & $\begin{array}{c}\text { Charge } \\
3+\end{array}$ & Resin \\
\hline $5 \mathrm{~min}$ & 0 & 3.5 & 2.7 & 23.7 & 68.0 & 2.0 \\
$5 \mathrm{~min}$ & 0 & 5.1 & - & 20.4 & 71.7 & 2.8 \\
$5 \mathrm{~min}$ & $2 \mathrm{~h}$ & 2.6 & 2.5 & 21.5 & 72.2 & 1.3 \\
$5 \mathrm{~min}$ & $96 \mathrm{~h}$ & 1.8 & 4.1 & 16.1 & 75.2 & 2.7 \\
$25 \mathrm{~min}$ & 0 & 0.6 & 2.9 & 14.0 & 82.5 & - \\
$+1 \mathrm{~h}$ & 0 & 5.9 & - & 9.5 & 82.2 & 2.3 \\
\hline
\end{tabular}

The reaction of trace $\mathrm{Cr}(\mathrm{VI})$ with trifluoromethanesulfonic acid

The results for the reaction $(1 \mathrm{~h})$ of high specific activity ${ }^{51} \mathrm{Cr}(\mathrm{VI})$ with $\mathrm{CF}_{3} \mathrm{SO}_{3} \mathrm{H}$ showed that $47 \%$ of the ${ }^{51} \mathrm{Cr}$ is observed as a $3+$ species, $28 \%$ as $2+$ species and $2 \%$ as $1+$, while $14 \%$ was not retained on the cation column, indicating anionic and/or neutral species (Table 5 and Figure 5). Aquation studies suggest these to be $\mathrm{Cr}(\mathrm{III})$ species. These results show that the trifluoromethanesulfonate anion more readily forms complexes with $\mathrm{Cr}(\mathrm{III})$ than does perchlorate.

\section{The reaction of trace $\mathrm{Cr}(\mathrm{VI})$ with concentrated nitric acid}

The ion chromatographic analysis for the ${ }^{51} \mathrm{Cr}(\mathrm{VI})$ $65 \% \mathrm{HNO}_{3}$ system showed that, after 60 min of reaction, 


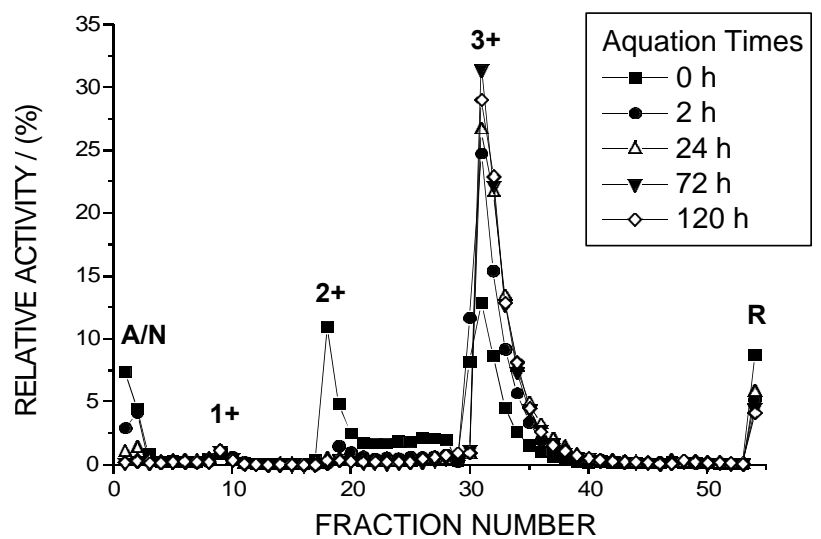

Figure 5. Cation exchange chromatograms of the products from the reaction $(1 \mathrm{~h})$ of high specific activity ${ }^{51} \mathrm{Cr}(\mathrm{VI})$ and $99 \% \mathrm{CF}_{3} \mathrm{SO}_{3} \mathrm{H}$ and after post reduction aquation.

Table 5. Summary of products (\%), observed after different reaction times, $\mathrm{t}(\mathrm{conc})$, and after specified aquation times, $\mathrm{t}(\mathrm{dil})$, from trace ${ }^{51} \mathrm{Cr}(\mathrm{VI})$ reacting with concentrated $\mathrm{CF}_{3} \mathrm{SO}_{3} \mathrm{H}$

\begin{tabular}{lcccccc}
\hline $\mathrm{t}$ (conc) & $\mathrm{t}$ (dil) & $\begin{array}{c}\text { Anionic/ } \\
\text { Neutral }\end{array}$ & $\begin{array}{c}\text { Charge } \\
1+\end{array}$ & $\begin{array}{c}\text { Charge } \\
2+\end{array}$ & $\begin{array}{c}\text { Charge } \\
3+\end{array}$ & Resin \\
\hline $1 \mathrm{~h}$ & 0 & 13.7 & 1.7 & 27.6 & 47.6 & 9.4 \\
$1 \mathrm{~h}$ & $2 \mathrm{~h}$ & 8.4 & 2.1 & 6.6 & 76.6 & 6.3 \\
$1 \mathrm{~h}$ & $24 \mathrm{~h}$ & 3.3 & 2.2 & 1.8 & 86.4 & 6.2 \\
$1 \mathrm{~h}$ & $72 \mathrm{~h}$ & 1.9 & 1.6 & 1.2 & 90.3 & 5.0 \\
$1 \mathrm{~h}$ & $120 \mathrm{~h}$ & 1.8 & 1.5 & 1.7 & 90.1 & 4.8 \\
\hline
\end{tabular}

the major part of the ${ }^{51} \mathrm{Cr}(60 \%)$ was present as a $2+$ species, while $34 \%$ appeared as a $3+$ species and only $0.3 \%$ as anionic/neutral species. These results are consistent with an earlier study. ${ }^{47}$ As shown in Figure 6, aquation was relatively rapid, producing $3+$ species. An interesting feature was the relatively high amount $(7 \%)$ of ${ }^{51} \mathrm{Cr}$-labelled species that remains on the resin after the passage of all eluents. This species hydrolyzed only slowly when stored in $0.01 \mathrm{~mol} \mathrm{~L}^{-1} \mathrm{HNO}_{3}$ (Table 6). .

The reaction of trace $\mathrm{Cr}(\mathrm{VI})$ with aqueous solutions of nitric acid

When trace ${ }^{51} \mathrm{Cr}(\mathrm{VI})$ is placed in dilute aqueous $\mathrm{HNO}_{3}$, the $\mathrm{Cr}(\mathrm{VI})$ concentrations decreased with time. Figure 7 shows the results for seven different solutions with initial concentrations of $\mathrm{Cr}(\mathrm{VI})$ of $10^{-6} \mathrm{~mol} \mathrm{~L}^{-1}$ and nitric acid concentrations of $2,1,10^{-1}, 10^{-2}, 10^{-3}, 10^{-4}$ and $10^{-5} \mathrm{~mol} \mathrm{~L}^{-1}$.

In agreement with other workers, ${ }^{13,20,21}$ these results show that low concentrations of $\mathrm{Cr}(\mathrm{VI})$ are not stable in an acid solution, an observation which has implications with respect to the storage of $\mathrm{Cr}(\mathrm{VI})$ solutions in studies of environmental speciation. Figure 7 indicates that the reduction velocity is proportional to the nitric acid

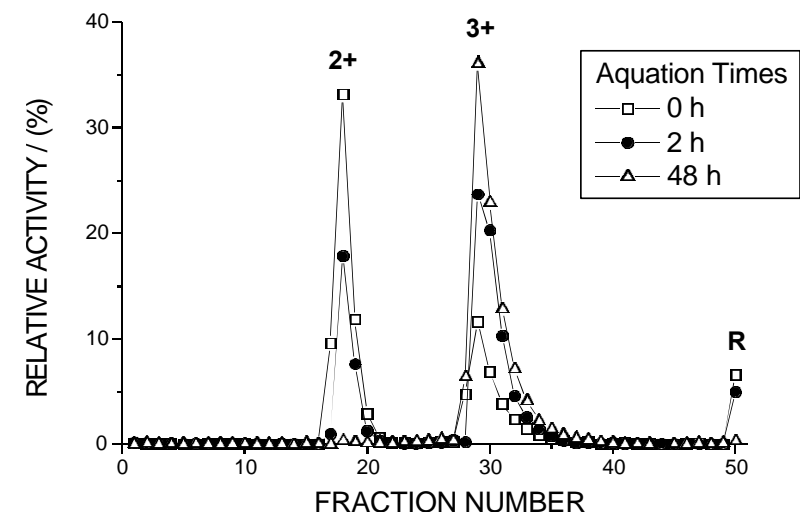

Figure 6. Cation exchange chromatograms of the products from the reaction $(1 \mathrm{~h})$ of high specific activity ${ }^{51} \mathrm{Cr}(\mathrm{VI})$ and $65 \% \mathrm{HNO}_{3}$ and after post reduction aquation.

Table 6. Summary of products (\%), observed after different reaction times, $t($ conc $)$, and after specified aquation times, $t(d i l)$, from trace ${ }^{51} \mathrm{Cr}(\mathrm{VI})$ reacting with concentrated $\mathrm{HNO}_{3}$

\begin{tabular}{lcccccc}
\hline $\mathrm{t}$ (conc) & $\mathrm{t}$ (dil) & $\begin{array}{c}\text { Anionic/ } \\
\text { Neutral }\end{array}$ & $\begin{array}{c}\text { Charge } \\
1+\end{array}$ & $\begin{array}{c}\text { Charge } \\
2+\end{array}$ & $\begin{array}{c}\text { Charge } \\
3+\end{array}$ & Resin \\
\hline $1 \mathrm{~h}$ & 0 & 0.3 & 0.3 & 59.0 & 33.8 & 6.6 \\
$1 \mathrm{~h}$ & $2 \mathrm{~h}$ & 0.5 & 0.2 & 28.9 & 65.4 & 5.0 \\
$1 \mathrm{~h}$ & $48 \mathrm{~h}$ & 0.2 & - & 1.4 & 98.0 & 0.4 \\
\hline
\end{tabular}

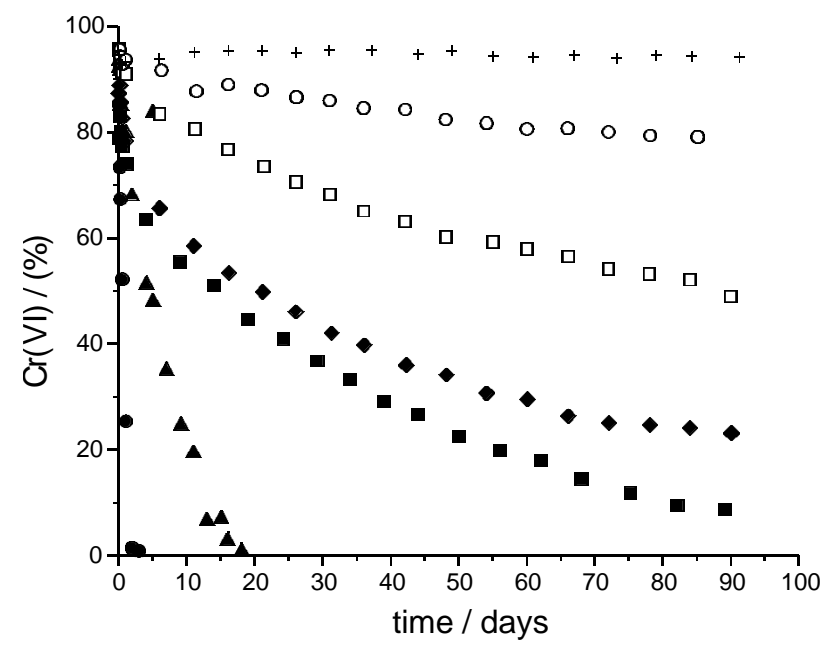

Figure 7. Reduction kinetics of $10^{-6} \mathrm{~mol} \mathrm{~L}^{-1}{ }^{51} \mathrm{Cr}(\mathrm{VI})$ in the presence of different concentrations of $\mathrm{HNO}_{3} \cdot \boldsymbol{\bullet}=2 \mathrm{~mol} \mathrm{~L}^{-1}, \boldsymbol{\Delta}=1 \mathrm{~mol} \mathrm{~L}^{-1}$, $\mathbf{\square}=10^{-1} \mathrm{~mol} \mathrm{~L}^{-1}, \diamond=10^{-2} \mathrm{~mol} \mathrm{~L}^{-1}, \square=10^{-3} \mathrm{~mol} \mathrm{~L}^{-1}, \bigcirc=10^{-4} \mathrm{~mol} \mathrm{~L}^{-1}$, $+=10^{-5} \mathrm{~mol} \mathrm{~L}^{-1}$.

concentration. A similar behavior is observed for higher $\mathrm{Cr}(\mathrm{VI})$ concentrations although the relative reduction velocities decreased as the $\mathrm{Cr}(\mathrm{VI})$ concentration increased.

A complete chromatographic analysis on the first fraction eluted from an anion exchange analysis (containing the cationic and neutral species), showed that 
the radioactivity related to $\mathrm{Cr}$ (III) is distributed among several species, the most prominent being the hexaaquo ion, and that this distribution changed with time. Polymeric $\mathrm{Cr}$ (III) species became more important as the concentration of $\mathrm{Cr}(\mathrm{VI})$ increased. These polymeric species change even more slowly with storage than do the monomeric species, in agreement with published results. ${ }^{48}$

\section{Comparison of the behavior of trace Cr(VI) in different acids}

The major initial reduction products from perchloric, trifluoromethanesulfonic and nitric acids were $2+$ and $3+$, although the analysis also indicated the presence of anionic/neutral, 1+ and higher polymeric species (Figures 4-6). On storage in $0.01 \mathrm{~mol} \mathrm{~L}^{-1}$ acid, the monomeric $2+$ and $1+$ species underwent aquation forming hexaaquochromium(III). Reduction in these concentrated acids formed small amounts (2-9\%) of polymeric species which were retained by the cation resin. The product from reduction in perchloric acid was relatively resistant to depolymerization. By contrast, the higher charged species produced by reduction in $99 \% \mathrm{CF}_{3} \mathrm{SO}_{3} \mathrm{H}$ or $65 \% \mathrm{HNO}_{3}$ underwent depolymerization upon aquation in $0.01 \mathrm{~mol}$ $\mathrm{L}^{-1}$ acid. It should be noted that none of the chromatograms indicated the presence of dimeric and/or trimeric species eluting with $1 \mathrm{~mol} \mathrm{~L}^{-1} \mathrm{Ca}\left(\mathrm{ClO}_{4}\right)_{2}$ at $\mathrm{pH} 2$, even though some species were retained by the cation exchange column.

When these results are compared to those observed with the other acids (Figures 1-3), some significant differences are noted. The major product when trace concentrations of ${ }^{51} \mathrm{Cr}(\mathrm{VI})$ reacts with concentrated $\mathrm{CF}_{3} \mathrm{SO}_{3} \mathrm{H}, \mathrm{HNO}_{3}$ and $\mathrm{HClO}_{4}$ is the $3+$ species, $\mathrm{Cr}\left(\mathrm{H}_{2} \mathrm{O}\right)_{6}^{3+}$, and the smaller amounts of $1+$ and $2+$ species are rapidly converted to the $3+$ species on aquation. By contrast, when trace ${ }^{51} \mathrm{Cr}(\mathrm{VI})$ reacts with $\mathrm{HCl}, \mathrm{HF}$ or $\mathrm{H}_{2} \mathrm{SO}_{4}$, complexed species, $\mathrm{Cr}\left(\mathrm{H}_{2} \mathrm{O}\right)_{3} \mathrm{Cl}_{3}, \mathrm{Cr}\left(\mathrm{H}_{2} \mathrm{O}\right)_{3} \mathrm{~F}_{3}$ and $\mathrm{Cr}\left(\mathrm{H}_{2} \mathrm{O}\right)_{2}\left(\mathrm{SO}_{4}\right)_{2}$, respectively, are the main initial products. As chloride, fluoride and sulfate form very much stronger complexes with $\mathrm{Cr}$ (III) than do trifluoromethanesulfonate, perchlorate and nitrate, this is not an unexpected result. On the other hand, even the small amounts of $2+$ and $1+$ species seen with the "non-complexing" anions suggests that the mechanism of the reduction reaction probably involves a ligand capture step to form complexes.

The results reported here on the reduction of $\mathrm{Cr}(\mathrm{VI})$ in solutions of several oxidizing acids, not involving a conventional reducing species such as chloride, suggest that "acid", i.e., the proton, may be a defining reagent in the reduction pathway. Archundia et al. ${ }^{12}$ in discussing the reduction of $\mathrm{Cr}(\mathrm{VI})$ in formic acid, concluded that the process is promoted by $\mathrm{H}^{+}$and is perhaps independent of the nature of the acid anion, although the latter may participate to form $\mathrm{CrL}_{\mathrm{n}}$-type species. Thus, the role of the different anions present, which depend on the acid used, should contribute importantly, as they form complexes (pseudo-esters) whose stability may influence the overall kinetics of the acid-reduction process and the resulting product distributions.

\section{Conclusions}

The results indicate that low concentrations of $\mathrm{Cr}(\mathrm{VI})$ are reduced by concentrated acids forming hexaaquochromium(III) and other complexes of $\mathrm{Cr}(\mathrm{III})$, which can be separated by chromatographic methods. In any media and with any reducing agent, the overall process whereby ${ }^{51} \mathrm{Cr}(\mathrm{VI})$ is reduced to ${ }^{51} \mathrm{Cr}(\mathrm{III})$ is probably a multistep one, since three electrons must be transferred to produce $\mathrm{Cr}(\mathrm{III})$. The appearance of $\mathrm{Cr}(\mathrm{III})$ species bonded to one, two or even three anions suggests the direct participation of the anion in the electron transfer process.

Thus, acidic $\mathrm{Cr}(\mathrm{VI})$ standard solutions and procedures for the determination of chromium in metal alloys ${ }^{49}$ and biological materials,${ }^{50}$ which are based on acid dissolution of the sample in $\mathrm{HClO}_{4}$ or another strong acid, followed by $\mathrm{Cr}(\mathrm{VI})$ determination using spectrophotometric or titrimetric procedures, must be used with caution due to this complicating factor of acid-induced reduction.

\section{Acknowledgements}

The authors thank the National Research Council (CNPq) and the São Paulo State Research Foundation (FAPESP) for fellowships and financial support.

\section{References}

1. Weeks, M. E.; Leicester, H. M.; Discovery of the Elements, $7^{\text {th }}$ ed., American Chemical Society: Easton, 1968.

2. Feigl, F.; J. Chem. Educ. 1943, 20, 240.

3. Westheimer, F.H.; Chem. Rev. 1949, 45, 419.

4. Wiberg, K.B.; Oxidation in Organic Chemistry, Part A, Academic: New York, 1965.

5. Cainelli, G.; Cardillo, G.; Chromium Oxidations in Organic Chemistry, Springer-Verlag: Berlin, 1984.

6. Das, A. K.; Oxid. Commun. 2001, 24, 321.

7. Beattie, J. K.; Haight Jr., G. P.; Prog. Inorg. Chem. 1972, 17, 93.

8. Fendorf, S.; Wienlinga, B. W.; Hansel, C. M.; Int. Geol. Rev. 2000, 42, 691.

9. Smith, G. F.; Ind. Eng. Chem. Anal. Edition 1934, 6, 229. 
10. Bobtelsky, M.; Glasner, A.; J. Chem. Soc. 1948, 1376.

11. Ho, W.-H.; Proc. Natl. Sci. Counc. ROC 1979, 4, 1.

12. Archundia, C.; Collins, C. H.; Collins, K. E.; J. Radioanal. Nucl. Chem. Lett. 1990, 146, 49.

13. Archundia, C.; Bonato, P.S.; Lugo Rivera, J.F.; Mascioli, L.C.; Collins, C.H.; Collins, K.E.; Sci. Total Environ. 1993, 130/ 131, 231.

14. Archundia, C.; Lugo Rivera, J. F.; Collins, K. E.; Collins, C. H.; J. Radioanal. Nucl. Chem. Art. 1995, 195, 363.

15. Pezzin, S. H.; Archundia, C.; Collins, C. H.; Collins, K. E.; Radiochim. Acta 1997, 77, 91.

16. Khan, Z.; Hashmi, A. A.; Din, K.; Transition Met. Chem. 1998, 23, 147.

17. Pezzin, S. H.; Collins, C. H.; Archundia, C.; Collins, K. E.; J. Radioanal. Nucl. Chem. 1998, 236, 209.

18. Pezzin, S. H.; Archundia, C.; Collins, K. E.; Collins, C. H.; Czech. J. Phys. 2000, 50, 315.

19. Pezzin, S.H.; Collins, C.H.; Collins, K.E.; Proceedings of the National Meeting on Nuclear Applications, Rio de Janeiro, Brazil, 2000, CD-ROM, paper no. 61.

20. Pavel, J.; Kliment, J.; Stoerk, S.; Suter, O.; Fresenius Z. Anal. Chem. 1985, 321, 587.

21. Stollenwerk, K. G.; Grove, D. B.; J. Environ. Qual. 1985, 14 , 386.

22. Gil, M.; Escolar, D.; Iza, N.; Montero, J. L.; Appl. Spectrosc. 1986, 40, 1156.

23. Tong, J.Y.P.; King, E.L.; J. Am. Chem. Soc.1960, 82, 3805.

24. Espenson, J.H.; King, E.L.; J. Am. Chem. Soc. 1963, 85, 3328

25. Khan, Z.; Din, K.; Indian J. Chem. 2001, 40A, 528.

26. Haight Jr., G. P.; Richardson, D. C.; Coburn, N. H.; Inorg. Chem. 1964, 3, 1777.

27. Espenson, J.H.; J. Am.Chem. Soc. 1964, 86, 5101.

28. Pezzin, S. H.; Collins, C.H.; Collins, K.E.; Radiochim. Acta 2001, 89, 845.

29. House, D. A. In Mechanisms of Inorganic and Organometallic Reactions; Twigg, M. V., ed.; Plenum: New York, 1994, p. 97.

30. Sena, M. M.; Scarminio, I. S.; Collins, K. E.; Collins, C. H.; Talanta 2000, 53, 453.

31. Cruywagen, J. J.; Heyns, J. B. B.; Rohwer, E. A.; Polyhedron 1998, 17, 1741.
32. Brito, F.; Ascanio, J.; Mateo, S.; Hernandez, C.; Araujo, L.; Gili, P.; MartinZarza, P.; Dominguez, S.; Mederos, A.; Polyhedron 1997, 16, 3835.

33. Nriagu, J. O.; Nieboer, E.; Chromium in the Natural and Human Environments, Wiley: New York, 1988.

34. Collins, C. H.; Pezzin, S. H.; Lugo Rivera, J. F.; Bonato, P. S.; Windmöller, C.; Archundia, C.; Collins, K. E.; J. Chromatogr. A 1997, 789, 469.

35. Marques, M. J.; Salvador, A.; Morales-Rubio, A.; de la Guardia, M.; Fresenius. J. Anal. Chem. 2000, 367, 601.

36. Collins, K. E.; Bonato, P. S.; Archundia, C.; de Queiroz, M. E. L. R.; Collins, C. H.; Chromatographia 1988, 26, 160.

37. Collins, C. H.; Collins, K. E.; Ackerhalt, R. E.; J. Radioanal. Chem. 1971, 8, 263.

38. de Andrade, J. C.; Collins, K. E.; Quim. Nova 1981, 4, 89.

39. Gates, H. S.; King, E. L.; J. Am. Chem. Soc. 1958, 80, 5011. 40. Autenrieth, W.; Ber. Deutsch. Chem. Ges. 1902, 35, 2057.

41. Krauss, H. L.; Leder, M.; Münster, G.; Chem. Ber. 1963, 96, 3008.

42. Finholt, J. E.; Ph.D. Thesis, Lawrence Radiation Laboratory Report UCRL-8879, University of California, Berkeley, 1960.

43. Collins, C. H.; Lanças, F. M.; Radiochem. Radioanal. Letters 1982, 19, 117.

44. Jones, K. M.; Bjerrum, J.; Acta Chem. Scand. 1965, 19, 974.

45. Aggett, J.; Udy, D. J.; J. Inorg. Nucl. Chem. 1970, 32, 2802.

46. Chaabouni, M.; Chausse, T.; Pascal, J. L.; Potier, J.; J. Chem. Res. (S) 1980, 72.

47. Archundia, C.; Collins, C. H.; Collins, K. E.; Proceedings of the Second General Congress on Nuclear Energy, Rio de Janeiro, Brazil, 1988, vol. 2, p.415.

48. Stünzi, H.; Marty, W.; Inorg. Chem. 1983, 22, 2145.

49. Annual Book of ASTM Standards, Section 3, Vol.03.05, Chemical Analysis of Metals and Metal-Bearing Ores, American Society for Testing and Materials; Philadelphia, 1985.

50. Ottaway, J. M.; Fell , G.S.; Pure Appl. Chem. 1986, 58, 1707. Received: September 16, 2002 Published on the web: January 7, 2004

FAPESP helped in meeting the publication costs of this article. 